\title{
COMMENTS
}

\section{THIRD-PARTY RECOVERY FOR INJURY TO ECONOMIC INTERESTS-A COMMON-LAW PROBLEM IN INTERPRETING THE ANTITRUST LAWS}

Barrison v. Paramount Pictures, Inc. ${ }^{1}$ is the most recent case raising the question of whether an injured third party may sue for treble damages under the Sherman and Clayton Acts. The third-party plaintiff, Mrs. Harrison, was the lessor of a motion picture theater; the tenant controlled the operation of the theater and, under the terms of the lease, paid as rental a fixed minimum amount plus a percentage of the receipts. The tenant had at all times paid the minimum rental, but his receipts, and thus the amounts paid by him under the percentage clause, had been kept down due to the trade practices of defendant motion picture companies, who had refused to permit exhibition of first-run pictures in the theater. The lessor claimed that defendants had violated the Clayton Act, ${ }^{2}$ that she had been damaged in her "business or property" under the percentage rent arrangement, and that she was therefore entitled to treble . damages. The court, however, denied recovery. ${ }^{3}$

The Harrison case is not one of first impression. Three other cases have decided the issue of whether a lessor may maintain a treble damages action when his tenant has been the direct victim of an antitrust violation. Two of these decisions upheld the lessor's capacity to sue, by denying motions to dismiss. In East Orange Amusement Co. v. Vitagraph, Inc., ${ }^{4}$ the landlord claimed that antitrust violations had caused his tenant to default in payment of rent, and that this default led in turn to the landlord's loss of his real estate to a mortgagee. And in Camrel Co., Inc. v. Paramount Film Distributing Corp..${ }^{5}$ the lessor claimed

1115 F. Supp. 312 (E.D. Pa., 1953).

2 "Any person who shall be injured in his business or property by reason of anything forbidden in the antitrust laws may sue therefor . . . without respect to the amount in controversy, and shall recover threefold the damages by him sustained, and the cost of suit, including a reasonable attorney's fee." 38 Stat. 731 (1914), 15 U.S.C.A. $\$ 15$ (1951).

${ }^{3}$ Upon trial the jury found no antitrust violation by the defendants. Plaintiff claimed that the trial judge erred in failing to direct a verdict, and that, therefore, a judgment notwithstanding the verdict should be entered for plaintiff. The defendant contended that the verdict was correct, and that, as a matter of law, the plaintiff had no standing to sue. The opinion was written on plaintiff's motion. Although the court refused to upset the verdict, it discussed the plaintiff's right of action as if a violation had been found; this note will deal with the problem upon the same assumption. Appeal in the Harrison case is now pending.

1 CCH Trade Cas. II 52,965 (D.C. N.J., 1943).

5 CCH Trade Cas. I 57,233 (S.D. N.Y., 1944). 
injury to rental and market value and, in addition, injury under a percentage rent agreement like that in the Harrison case, as a result of the alleged antitrust violations by the defendant. Neither court gave substantial treatment to the problem. The Camrel court, after reciting the plaintiff's claims of injury, dismissed the motion, saying only, "I think plaintiff has alleged sufficient to withstand a mere formal motion." The third case, Westmoreland Asbestos Co. v. Johns-Manville Corp., ${ }^{7}$ held, however, that the injuries to the landlord were too -remote to entitle him to maintain the action. The court dismissed the complaints of one Kuenn, stockholder and creditor of Westmoreland Company, and of Kuenn, Inc., landlord of Westmoreland, without useful discussion. The result in the Harrison case, then, evened the split in the cases at two to two.

The Harrison opinion was the first to deal fully with the problems peculiar to a suit by a lessor. The court adopted two alternative lines of argument: first, that a lessor's interest was such that there could be no injury in "his business or property," as required by the Act; second, that even if there were injury to business or property within the meaning of the statute, it would be too remote to be compensable. As to the first contention, it should be observed that Mrs. Harrison accepted a lower minimum rental, as well as a share of the risks of the business, in return for expectations of a percentage of the receipts. But in accepting some part of the business risks, she would appear to be entitled to rely on statutory remedies whose purpose is to reduce such risks. Although, in the court's words, Mrs. Harrison's expectation of sharing in receipts may have been no more than a "hope,"8 it would seem to be a hope which should not be impaired, without remedy, by violations of the law. This point had been conceded by the defendants, who admitted, in their brief, that the plaintiff could have suffered injury. ${ }^{9}$ Moreover, the no "injury in his business or property" argument appears to be in conflict with the policy implicit in the Supreme Court's decision in Bigelow v. RKO Radio Pictures, Inc.10-that courts should not deny relief under the Acts where any injury can be proven. The primary issue, then, is whether the plaintiff's interests can properly be said to be too remote to be

'Tbid., at $\llbracket 57,326$.

730 F. Supp. 389 (S.D. N.Y., 1939).

8115 F. Supp. 312, 316 (E.D. Pa., 1953).

- Defendants' Brief Contra Plaintiff's Motion for Judgment N. O. V., at 20. They say [speaking of Conference of Studio Unions v. Loew's Inc., 193 F. 2d 51 (C.A. 9th, 1951)]: "The court granted judgment on the correct ground-not that there was no injury to plaintiffs, but
that the injury was merely incidental, and therefore not within the purview of the antitrust laws.

"This, we submit, is the proper basis on which to consider the matter and it must result in holding that the plaintiff in our case had no status."

10327 U.S. 251 (1946). The court stated that: "in the absence of more precise proof, the jury could conclude as a matter of just and reasonable inference from the proof of defendants' wrongful acts and their tendency to injure plaintiffs' business, and from the evidence of the decline in prices, profits and values, not shown to be attributable to other causes, that defendants' wrongful acts had caused damage to the plaintiffs." Thid., at 264. 
protected; if the remoteness question is decided in the plaintiff's favor, it seems highly unlikely that any court would then find that the interests injured do not constitute "business or property."

Lessors have not been the only third-party plaintiffs to bring actions for treble damages under the Sherman and Clayton Acts. Courts have been uniform in denying recovery to shareholders, ${ }^{11}$ creditors, ${ }^{12}$ and deposed officers of corporations ${ }^{13}$ damaged by antitrust violations. Sales agents, on the other hand, have been permitted to recover lost commissions from the violator. ${ }^{14}$ The cases, however, do not make clear why the interest of a sales agent is considered to be less remote than those of the other third-party plaintiffs; these courts stress the existence of an "injury to business," but do not deal with the remoteness problem. However, the divergence in result between the stockholder-creditor cases and the sales agent cases is not overly disturbing. To permit individual shareholder's suits would be to disregard one of the basic purposes of the corporate entity. Direct recovery to the individual creditor would give him a preference over other creditors of the insolvent business; such recovery would act to thwart the policies of the bankruptcy laws. Further, the number of shareholders and creditors makes the multiplicity of suit problem almost insurmountable. These elements are not present in the sales agent situation, and may justify the difference in result. But there is no corporate entity, nor is there a serious multiplicity of suit problem in the Harrison case; thus it would seem more logical that the Harrison result accord with that of the sales agent cases, rather than that of cases involving stockholders or creditors.

Thus, neither in terms of logic, dictum, nor uniformity of result have the cases under the Acts been of assistance in determining the standing to sue of third-party plaintiffs. Where the important criteria of decision are not disclosed, they may vary from one case to the next. Judge Kirkpatrick, in his Harrison opinion, seems to be resigned to this state of affairs, for he says:

It is not possible to formulate any general rule by which to determine what injuries are too remote to bring a plaintiff within the scope of the Act and I shall not attempt to do so. Each case must be dealt with on its own facts. All that is decided here is that this plaintiff's loss, if any, is beyond the limit of injuries cognizable under the anti-trust laws..$^{15}$

${ }^{11}$ E.g., Gerli v. Silk Ass'n of America, 36 F. 2 d 959 (S.D. N.Y., 1929); Loeb v. Eastman Kodak Co., 183 Fed. 704 (C.A. 3d, 1910).

12 E.g., Loeb v. Eastman Kodak, 183 Fed. 704 (C.A. 3d, 1910).

13 E.g., Corey v. Boston Ice Co., 207 Fed. 465 (D.C. Mass., 1913).

14 Roseland v. Phister Mfg. Co., 125 F. 2d 417 (C.A. 7th, 1942); in McWhirter v. Monroe Calculating Mach. Co., 76 F. Supp. 456 (W.D. Mo., 1948), and Klein v. Sales Builders, Inc., CCH Trade Cas. I 62,600 (N.D. Ill., 1950), it was held that sales agents were proper parties plaintiff; however, judgment on the merits was rendered against the plaintiff when insufficient proof of injury was made. Klein v. Sales Builders; Inc., CCH Trade Cas. Il 62,950 (N.D. Ml., 1951).

15115 F. Supp. 312, 317 (E.D. Pa., 1953). 
Apart from the cases, it would seem that assistance in determining the scope of permissible. plaintiffs might be derived from the policy underlying treble damages. There are, however, at least three ways of interpreting the treble damages provisions: first, that in view of the severity of the penalty, the scope of liability should be narrowed from what it would be at common law; alternatively, that if the policy of the act is so strong as to warrant such a penalty provision, full support of that policy requires the scope to be extended beyond the common-law limits; or, finally, that the allowance of the treble damage remedy should in no way change the effect of the common-law remoteness criteria.

All three viewpoints may be found expressed in decisions under the antitrust laws. The court in Corey v. Independent Ice Co. ${ }^{16}$ read the statute as narrowing the common-law remedies. In denying an equitable remedy under the Act to minority stockholders, the court decided that "neither [plaintiffs] nor their corporation could claim any right whatever to such damages except so far as the act has expressly given such a right, and the express provisions of the act are not of a character such as permits extending them by implication." 17 On the other hand, the court sitting in Bigelow v. Calumet \& Hecla Mining Co. ${ }^{18}$ allowing an injunction to issue, stated: "I cannot overlook the fact that the federal anti-trust act is highly remedial. Its apparent object is not to restrict, but to extend, remedies. ... The very penal provisions invoked by defendant's counsel as requiring a strict construction of the act are but evidence of the highly remedial nature of the statute. ..."19 Finally, the court in Loeb v. Eastman Kodak Co. ${ }^{20}$ refusing to change the common-law rule denying actions by individual stockholders for wrongs to the corporation, stated: "The statute above referred to was passed, as we must assume, with full knowledge of the existing law in that respect. We have no reason to suppose, much less to assume, that it was intended thereby to run contrary to the settled policy of the law."2I

Far from being an aid in properly interpreting the statute, the treble damages provisions pose problems of their own. Suppose, in the Harrison case, that the tenant had sued, and recovered treble damages from the defendants. How should the damages then be apportioned between landlord and tenant? The landlord might take only compensatory damages, to the extent of her percentage; the lease agreement refers to percentages of "receipts," and it involves some stretching to bring penalty damages within the meaning of that term. And it may be argued that the landlord did not bargain for the possibility of penalty damages and should not be allowed to share in them. On the other hand, the lease might be viewed as a risk-sharing arrangement; if the landlord, under

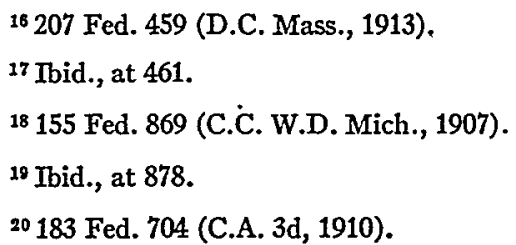

21 Ibid., at 709. 
the percentage agreement, assumed some part of the risk of torts against the business, then she would seem entitled to share fully in any recovery. Moreover, to limit the lessor to compensatory damages would create a windfall for the tenant, who would receive three times his own loss plus twice the amount of the landlord's loss. From this view, it would seem that the landlord should share in the entire recovery.

In summary, neither the cases under the Acts nor discussions of the policy supporting treble damages are helpful in defining clearly the range of permissible plaintiffs. However, the Harrison case, and the other third-party suits under the Acts, are but particular instances of a general tort problem - the right of a third party to sue for any tort committed against one with whom he has a contract, when the result is to make that contract less profitable. If a conclusion can be reached on the more general level, as to whether such third-party plaintiffs have or should have a right of action, the criteria for decision in the antitrust sphere will almost certainly be clarified.

II

The Harrison situation presents a problem on which two great tort doctrines bear. The similarity with the Lumley v. Gye22 situation is apparent; in each, the plaintiff loses the benefit of a contract due to a wrongful act by the defendant. In the Harrison case, however, the defendants did not know of the plaintiff's contract, nor did they intend to cause its breach. To allow recovery under Lumley-Gye theory would involve an extension of that doctrine to cases where interference with the contractual relationship was not specifically intended; the courts have been loath to make such an extension. ${ }^{23}$ Secondly, the Harrison situation can be viewed as raising a proximate cause question analogous to that in the Palsgraf case. ${ }^{24}$ But there is no foreseeability problem in the Harrison scheme; the plaintiff is usually a foreseeable person, such as a lessor, and recovery would seem to be dictated. Unlike Palsgraf, however, the damage here is economic rather than physical. 25

The leading case in the Harrison area is Robins Dry Dock \& Repair Co. v. Flint, ${ }^{26}$ where the general rule was stated by Justice Holmes: "a tort to the person or property of one man does not make the tortfeasor liable to another

$=2$ El. \& Bl. 216, 1 Eng. Rul. Cas. 706 (Q.B., 1853).

${ }^{23}$ Consult Foreseeability of Third-Party Economic Injuries-A Problem in Analysis, 20 Univ. Chi. L. Rev. 283 (1953); Harper, Interference with Contractual Relations, 47 Nw. U.L. Rev. 873 (1953); Carpenter, Interference with Contract Relations, 41 Harv. L. Rev. 728 (1928).

${ }^{24}$ Palsgraf v. Long Island R. Co., 248 N.Y. 339, 162 N.E. 99, 59 A.L.R. 1253 (1928).

${ }^{25}$ Compare the juxtaposition of Newlin v. New England T. \& T. Co., 316 Mass. 234, 54 N.E. $2 d 929$ (1944) (physical damage), and Stevinson v. East Ohio Gas Co., 47 Ohio Law Abs. 586,73 N.E. $2 \mathrm{~d} 200$ (1946) (damage to economic interests), in Seavey, Keeton, and Thurston, Cases on Torts 382, 383 (1950); and consult Foreseeability of Third-Party Economic Injuries A Problem in Analysis, 20 Univ. Chi. L. Rev. 283 (1953).

${ }^{2} 275$ U.S. 303 (1927). 
merely because the injurred person was under contract with that other, unknown to the doer of the wrong. . . . The law does not spread its protection so far."27 The rationale of the rule is the fear of the courts of extending too far liability for the negligent act. That this is a real problem is graphically illustrated by Stevinson v. East Ohio Gas Co. ${ }^{28}$ there, an explosion caused several factories to shut down, throwing hundreds out of work, each a potential third-party plaintiff. The court, denying recovery to one of the injured employees, said:

If one who by his negligence is legally responsible for an explosion or a conflagration should be required to respond in damages not only to those who have sustained personal injuries or physical property damage but also to every one who has suffered an economic loss, by reason of the explosion or conflagration, we might well be appalled by the results that would follow..$^{9}$

Granting that limitation of liability is a valid reason for denying recovery, it does not follow that this result is appropriate in every third-party action. In cases where there is no problem of extending defendants' liability, but only of apportionment of damages between injured parties, the Stevinson rationale is not applicable, and its rule should not be indiscriminately applied. For example, where a negligent party inflicts permanent damage upon leased property, the courts find no difficulty in awarding damages to both the interests involved, that is, to the tenant and to the holder of the reversion. ${ }^{30}$ There is no limitation of liability question here, for the quantum of damages is fixed. The injury to the land is only so great, and defendant can be forced to pay only that amount; how the recovery is divided among those with interests in the land is of no consequence to the defendant. This analysis would have allowed recovery in the Harrison case, for the problem in a percentage-of-profits lease is not essentially different. The antitrust violation has decreased the receipts of the enterprise by an amount which, under the theory of the Act, must be ascertainable. ${ }^{32}$ The

27 Tbid., at 309. The rule is also stated in 1 Sutherland, Damages $\$ 33$ (4th ed., 1916): "Where the plaintiff is injured by the defendant's conduct to a third person it is too remote if he sustains no other than a contract relation to such third person, or is under contract obligation on his account, and the injury consists only in impairing the ability or inclination of such third person to perform his part, or in increasing the plaintiff's expense or labor of fulfilling such contract, unless the wrongful act is wilful for that purpose."

One exception to this rule denying third-party recovery is the master-servant cases, where masters have traditionally been able to recover for wrongful injuries to servants. This doctrine, however, has been narrowly applied. United States v. Standard Oil Co., 332 U.S. 301 (1947); United States v. Atlantic Coast Line R. Co., 64 F. Supp. 289 (E.D. N.C., 1946). Contra: Attomey-General v. Valle-Jones [1935] 2 K.B. 209.

2847 Ohio Law Abs. 586, 73 N.E. 2d 200 (1946).

${ }^{29}$ Tbid., at 592 and 203.

30 "It is well settled that both the tenant and landlord may maintain actions for injuries done to the soil, or buildings upon it. They are both injured, but in different degrees; the tenant in the interruption to his estate and the diminution of his profits, and the landlord in the more permanent injury to his property. Both may have separate actions for their several damages, and a recovery is to be had according to their respective interests." George v. Fiske, 32 N.H. 32, 45 (1855).

${ }^{31}$ Consult note 10 supra. 
tenant may recover damages for these lost profits. Upon such recovery, Mrs. Harrison would be entitled to her percentage of the damages awarded in place of the lost receipts. And allowing Mrs. Harrison to recover directly would not increase the defendant's total liability beyond the amount recoverable by the lessee.

However, the rule of the Robins Dry Dock case has been of such pervasive influence that courts have seldom distinguished those third-party cases where recovery would extend the tortfeasor's liability from those where it would not. But there is at least one group of cases which have, to some degree, rejected the Robins rule. These cases concern fishing expeditions where it is the practice for the crew to be paid by sharing in the catch, along with the owners of the boats. The Ninth Circuit, in the recent case of Carbone v. Ursich, ${ }^{32}$ held that fishermen employed under such a contract could recover, in their own names, from one who had negligently fouled the boat's nets. This decision expressly overruled a prior decision of the Ninth Circuit denying recovery on the basis of the Robins Dry Dock case. ${ }^{33} \mathrm{~A}$ Federal district court in Lind $v$. United States, ${ }^{34}$ a case where the masters of both ships were found to be negligent, held the owner of each ship liable to the crew members of the fishing vessel for full damages. These courts, seeing no problem of extending the tortfeasor's liability, allowed a right of action to the crew although the "direct" tort was against the owner, thus making whole, directly, all parties injured. ${ }^{35}$ But even in the confines of the "fishingboat" cases, there are strong holdings following the traditional rule of no recovery. ${ }^{36}$

Suits by insurers in their own name to recover money paid in satisfaction of tort claims constitute an important instance of denial of third-party recovery despite the absence, in many cases, of a limitation of liability problem. The analogy between this problem and that of the Harrison case is close. As has been noted, a percentage-of-profits lessor, much like an insurer, contracts to assume certain risks of the business, among which may be that of reduced profits resulting from tortious acts of others. The common-law rule would deny recovery to the insurer, as to the lessor. However, in some cases the doctrine of subrogation may be available to permit recovery by the insurer; no similar doctrine is present to assist the lessor.

Rockingham Mutual Fire Ins. Co. v. Bosher ${ }^{37}$ is illustrative of the group of

2209 F. 2d 178 (C.A. 9th, 1953).

${ }^{33}$ Borcich v. Ancich, 191 F. 2d 392 (C.A. 9th, 1951).

3461 F. Supp. 329 (E.D. N.Y., 1945).

${ }^{35}$ Cf. The Mary Steele, 2 Low. 37, 16 Fed. Cas. 1003, No. 9,226 (D. Mass., 1874); The Columbia, 9 Ben. 254, 6 Fed. Cas. 173, No. 3,035 (E.D. N.Y., 1877).

${ }^{36}$ Baxter v. Rodman, 3 Pick. (Mass.) 435 (1826); Grozier v. Atwood, 4 Pick. (Mass.) 234 (1826); Taber v. Jenny, 1 Spr. 315, 23 Fed. Cas. 605, No. 13,720 (D. Mass., 1856).

3739 Me. 253 (1855). 
cases in which the insurer is without subrogation. ${ }^{38}$ The defendant wilfully burned the property of the insured. The plaintiff insurance company paid on the policy, but was denied a cause of action in its own name. Because the amount of damage caused by fire in cases of this nature can be readily computed, this is the clearest situation in which the courts' fear of unduly extending liability is groundless. In the usual case of property damage, subrogation is now allowed.

But subrogation is available in only a limited number of cases. It appears to -be the law that there can be no subrogation in part. ${ }^{39}$ Thus, if the amount of the policy is less than the amount of the loss, the insurer is entirely dependent upon the insured for his recovery from the tortfeasor. The reason for this rule is probably fear that the wrongdoer, as a result of a single negligent tort, might be subjected to a multiplicity of suits by insurance companies, as well, perhaps, as one by the insured for any loss not covered by the policies. ${ }^{40}$

Neither is subrogation available in life or accident insurance cases. ${ }^{41}$ These policies are seen as compensating the injured party for something other than that for which he recovers from the tortfeasor, in that the policy may be for an amount greater than that recoverable as tort damages by the insured. ${ }^{42}$ There are some instances in which this argument is valid; thus, if a man has a large life insurance policy, it might be that this amount would be beyond the "actual" value of his life, and that it would be unfair to a defendant to make him pay this amount to an insurance company for being so unlucky as to have negligently killed an "overinsured" man. However, it seems clear that very often the amount of the policy will be no more than the tort damages recoverable by the insured. In such a case, recovery by the insurer would involve no extension of the defendant's liability.

Subrogation, then, is not allowed when the defendant's liability may be extended. But when the amount of the insurance cannot exceed the tort damages recoverable by the insured, courts have surmounted the remoteness problem, and permitted recovery by the third-party insurer. ${ }^{43}$ However, it is highly un-

${ }^{38}$ Mobile Life Ins. Co. v. Brame, 95 U.S. 754 (1877); Conn. Mutual Life Ins. Co. v. N.Y* \& N.H. R. Co., 25 Conn. 265 (1856); Anthony v. Slaid, 11 Metc. (Mass.) 290 (1846); Town of Milton v. Story, 11 Vt. 101 (1839).

${ }^{39}$ Norwich Union Fire Ins. Soc. v. Standard Oil Co., 59 Fed. 984 (C.A. 8th, 1894); Fairgruve v. Marine Ins. Co. of London, 94 Fed. 686 (C.A. 8th, 1899); National Union Fire Ins. Co. v. Chesapeake \& O. Ry. Co., 4 F. Supp. 25 (E.D. Ky., 1933); Aetna Ins. Co. v. Hannibal \& St. J. R. Co., 3 Dill. 1, 1 Fed. Cas. 207, No. 96 (C.C. E.D. Mo., 1874); Vance, Insurance \$134 (3d ed., 1951).

${ }^{40}$ But see the explanation offered in Norwich Union Fire Ins. Soc. v. Standard Oil Co., 59 Fed. 984 (C.A. 8th, 1894).

41 Mobile Life Ins. Co. v. Brame, 95 U.S. 754 (1877); Crab Orchard Imp. Co.v. Chesapeake \& O. Ry. Co., 115 F. 2d 277 (C.A. 4th, 1940); Suttles v. Railway Mail Ass'n, 156 App. Div. 435,141 N.Y. Supp. 1024 (4th Dep't, 1913). But cf. Staples v. Central Surety \& Ins. Corp., 62 F. 2d 650 (C.A. 10th, 1932); Vance, Insurance $\$ 134$ (3d ed., 1951).

12 Compare Vance, Insurance $\$ 134$ (3d ed., 1951).

${ }^{43}$ In the case of property insurance, the amount of the policy clearly can never exceed the value of the property. Apparently, the right of subrogation exists even in the absence of a contract providing for it. Consult Vance, Insurance \$134 (3d ed., 1951). 
likely that any court would apply subrogation doctrine literally in the Earrison situation, although the central elements for its application are there present. First, there is, as has been noted, a single fixed amount of damages, beyond which the defendant's liability cannot be carried. Secondly, there has been a paying out by the lessor. Mrs. Harrison, in bargaining for the percentage arrangement, undoubtedly accepted a lower minimum rental than she would have otherwise. Thus, to that extent, the tenant has not been injured by the reduction of his receipts. If subrogation were here applicable, the lessor would have a cause of action, in her own name, for her share of the lost profits.44

Although the Robins Dry Dock case established the general rule denying recovery, the case itself is one where the defendant's liability was clearly limited, and in which the only real problem was one of apportionment. Defendant had negligently damaged a ship, so that it was not available for the use of the plaintiff charterer at the time specified in his contract with the owner. The Court of Appeals for the Second Circuit, allowing recovery, pointed out that "the result reached involves no injustice to respondent. Its liability for its tortious act is for the actual damages done to the combined interests in the ship. The measure of total recovery is the market value of the loss [of the use] of the ship."45 Under the theory of the Second Circuit, if the vessel were off hire when damaged, as in the case, the owner recovers for the lost charter hire, and the charterer receives the balance, that is, the difference between the charter hire . and the market value of the use. In the usual case, where the ship is not off hire, the charterer would recover the entire amount. However, although the loss is at least in part the charterer's, Justice Holmes could find no protection in the law for such a plaintiff.

The previous discussion points towards the conclusion that there exists a distinguishable body of cases in which third-party recovery has in the past been denied on limitation of liability grounds, but to which the argument is not properly applicable. Where the amount of the tortfeasor's liability is fixed and ascertainable, and where more than one interest is injured, it appears unreasonable to make contingent the recovery of some of the parties, forcing them to rely upon the party directly injured for relief. This is not to deny that there are cases where the fear of extending too far the defendant's liability is valid; the Stevinson case, with its numerous prospective plaintiffs, is argument enough. ${ }^{46}$ But the courts have failed to differentiate between those cases in which extension of liability would raise formidable questions and those in which it would not.

14 One important consideration not present in the Harrison case, but present in the insurance situation, is the question of whether, due to the superior risk-sharing capabilities of an insurer, policy might not dictate a denial of his right of action against the tortfeasor. James, Social Insurance and Tort Liability: The Problem of Alternative Remedies, 27 N.Y.U.L. Rev. 537 (1952); Friedmann, Social Insurance and the Principles of Tort Liability, 63 Harv. L. Rev. 241 (1949).

${ }^{45}$ Flint v. Robins Dry Dock \& Repair Co., 13 F. 2d 3, 5 (C.A. 2d, 1926).

${ }^{48}$ See discussion at note 28 supra. 
The line of distinction will not be a perfectly smooth one. There will often be a problem as to whether the particular case is one in which the defendant's lixbility is static, in which suit by one or several plaintiffs will not increase the amount of damages to be paid out. In Cattle v. Stockton Water Works, ${ }^{47}$ for example, the third-party plaintiff, a contractor, lost the benefit of his bargain with the party directly injured, as a result of the defendant's negligence. Recovery was denied. It seems clear that had the tort caused the intermediate party to - lose the benefit of his bargain with the third party, recovery would be available to him, although he could not recover for the third party's loss. To allow the third party to obtain recovery would extend the tortfeasor's liability..$^{48}$

Workmen's compensation insurance cases present another instance in which it may be difficult to determine whether third-party recovery would extend liability. For example, in Northern States Contracting Co. v. Oakes, ${ }^{49}$ defendant negligently killed one of plaintiff's employees; as a result, plaintiff was forced to pay increased amounts for workmen's compensation insurance. Recovery for the amount of the increase was denied. It appears, at first sight, that the position of the employer is similar to that of an insurer, and that recovery would be desirable. This situation, however, involves four parties, the insurer being the other party injured by the tort. Recovery by the insurer up to the amount of tort damages recoverable would not extend liability, but if, in addition, the employer could recover for his increased premiums, the amount of the tortfeasor's liability would be increased.

- Several questions remain unanswered. First, why is it not sufficient to let the party directly injured bring the suit, and let the third party get relief through him? Surely, in the usual case, it is in the interest of the directly injured party to bring action. And the courts have undoubtedly relied upon the intermediate party to seek relief on behalf of the injured third party, in denying the third party's capacity to sue. Nevertheless, there are cases where it is to the best interests of the intermediate party not to sue. The bringing of an action might jeopardize important business relationships. The intermediate party's share of the recovery might be very small, or the entire loss might be the third party's. Thus the interests of the two parties need not coincide; it seems clear that if her tenant had sought recovery, Mrs. Harrison's suit would have been unnecessary. ${ }^{50}$

${ }^{47}$ [1875] 10 Q.B. 453 . The facts are: the defendant negligently flooded some land at a time when plaintiff, a contractor, was doing work there for the owner; as a result, plaintiff was delayed in his work, and put to increased expense; he sued to recover his increased expense.

${ }^{48}$ It will be recalled that the lessor-plaintiffs in the antitrust cases claimed as injury the decrease in market value of their real estate as a result of the tenant's unsuccessful period of operation. In view of the fact that the tenant could not recover for this decrease in value, recovery by the lessor would result in extension of the defendant's liability.

49191 Minn. 88, 253 N.W. 371, 92 A.T.R. 1201 (1934).

${ }^{50}$ The possibility of insolvency of the intermediate party raises additional difficulties. If the third party has no direct cause of action, he may. never obtain the amounts recovered by the insolvent. On the other hand, to allow the third party to recover directly would in effect give him a preference over creditors. This result is not necessarily desirable. 
Another major problem is that of control of settlements. If reliance is placed upon the action of the intermediate party, he may settle for an insufficient amount. In the Robins Dry Dock case, the owner settled for an amount which exceeded his own loss, but did not cover that of the charterer. If the third party is foreclosed by such an agreement, the door is open for collusive settlements. On the other hand, if the intermediate party may settle only as to his own claim, and third parties retain an independent claim, settlements will be made more difficult, for defendants will fear that there may be some hidden third party whose claim is not being settled.

A final objection is that a direct third-party cause of action might require the tortfeasor to defend against multiple actions. But in many cases the actions will be joined; moreover, the common situation is where there will be only two plaintiffs, as in the Harrison case. In any event, the third party is innocent; the defendant is not.

Although direct third-party recovery has been found to be desirable in certain cases, the weight of precedent is opposed to it. Most of the cases involving injury to the economic interests of third parties have been disposed of on grounds of remoteness, and discussion has ended there. But further analysis has disclosed that this class of third-party actions is not uniform-that although some recoveries would extend liability, others would not. The distinction proposed would achieve the advantageous result of permitting third-party recovery where this is possible without increasing the amount of damages payable by the tortfeasor. In the absence of a discernible supervening policy, this distinction seems as appropriate to antitrust actions as to others.

\section{JUDICIAL EXERCISE OF EQUITABLE DISCRETION IN ENFORCEMENT OF ARBITRATION CONTRACTS}

A quarter of a century of experience with federal and state arbitration statutes has suggested to some observers that arbitration, despite its great usefulness in many situations, does not always achieve better results than could the courts. Many judges, brought into contact with arbitration contracts by virtue of statutory provisions for enforcement and review, have demonstrated their agreement with this evaluation. This attitude is most apparent in their frequent refusal to enforce such contracts at the outset of the arbitration process in cases in which they have felt more equitable results would be achieved through judicial procedures.

Opportunities for judicial influence over the outcome of arbitrable disputes are presented not only in review of arbitrator's decisions but at the several points at which statutes provide for judicial action before arbitration commences. A court may be asked to issue an order directly compelling the parties to arbitrate, to stay judicial proceedings where under the terms of the contract 